\title{
Experimental analysis of the impact of sluice regulation on water quality in the highly polluted Huai River Basin, China
}

\author{
Qiting Zuo (D) Hao Chen • Ming Dou • \\ Yongyong Zhang $\cdot$ Dongfeng Li
}

Received: 20 July 2014 / Accepted: 26 May 2015 / Published online: 20 June 2015

(C) Springer International Publishing Switzerland 2015

\begin{abstract}
Impact assessment of sluice regulation on water quality is one of the crucial tasks in the present river management. However, research difficulties remain because of insufficient in situ data and numerous influencing factors in aquatic environments. The Huaidian Sluice, the main control sluice of the Shaying River, China, was selected for this study. Three field experimental programs were designed and carried out to analyze spatial and temporal variations in water quality parameters under various sluice regulation conditions and to explore the impacts of regulation mechanisms on water quality. Monitoring data were used to simulate water quality under different scenarios by the water quality analysis simulation program (WASP). Results demonstrate that the influences of sluice regulation on permanganate index $\left(\mathrm{COD}_{\mathrm{Mn}}\right)$ and ammonia nitrogen $\left(\mathrm{NH}_{4}-\mathrm{N}\right)$ concentrations (indicators of water quality)
\end{abstract}

Q. Zuo $(\bowtie) \cdot$ H. Chen $\cdot$ M. Dou

School of Water Conservancy and Environment, Zhengzhou

University, Zhengzhou 450001, China

e-mail: zuoqiting@163.com

\section{Y. Zhang}

Key Laboratory of Water Cycle and Related Land Surface Processes, Institute of Geographic Sciences and Natural Resources Research, Chinese Academy of Sciences, Beijing 100101, China

D. $\mathrm{Li}$

School of Information Engineering, North China University of Water Resources and Electric Power, Zhengzhou 450045, China were complex and nonlinear and presented different trends of increase or decrease from different regulation modes. Gate openings of different widths and different flow rates affected $\mathrm{COD}_{\mathrm{Mn}}$ and $\mathrm{NH}_{4}-\mathrm{N}$ concentrations differently. Monitoring results and numerical simulation results indicate that the sluice opening should be small. Flow discharge through the sluice should be greater than $10 \mathrm{~m}^{3} \mathrm{~s}$ and less than $60 \mathrm{~m}^{3} \mathrm{~s}$ to maintain low $\mathrm{COD}_{\mathrm{Mn}}$ concentrations, and discharge should be low (e.g., $14 \mathrm{~m}^{3} \mathrm{~s}$ ) to maintain low $\mathrm{NH}_{4}-\mathrm{N}$ concentrations. This research provides an experimental basis for further research on the construction of water quality models and for the development of reasonable regulations on water quality and quantity.

Keywords Sluice regulation - Field experiment . Numerical simulation $\cdot$ Polluted river

\section{Introduction}

The construction of sluices and dams is an important strategy for the development and management of water resources. China has the largest number of dams and sluices in the world, and most rivers are fragmented (Zhang et al. 2010). The Huai River Basin, one of the largest river basins in China, has a high population density and serious water pollution problems. According to the statistics of the Ministry of Environmental Protection of the People's Republic of China (MEP; http://jcs. mep.gov.cn/), in 2012, tributaries of the Huai 
River, of which more than $60 \%$ state-controlled sections are not up to national standards (GB 3838-2002) (China State Environmental Protection Administration 2002), are moderately polluted. Sluices and dams can greatly affect aquatic environments; excessive sluice and dam construction may obstruct river flow, resulting in pollutant enrichment upstream of sluices. When flood water is discharged from the sluices, sudden water pollution events are prone to occur. The first such event occurred in the Huai River in 1975. After the 1990s, water pollution incidents occurred more frequently, and sudden pollution incidents of the Huai River occurred in 1994, 1999, 2001, and 2004. For example, the water pollution incident in 1994 caused a number of bubble clouds to form in the river; as a result, fish and shrimp died immediately, and some residents suffered from nausea, diarrhea, emesis, and other symptoms. Sudden pollution incidents and daily pollution incidents affect local people's daily life and productivity (Zuo et al. 2010). Research on the impacts of sluice and dam regulations on water quality in the polluted rivers can reduce the occurrence of water-related disasters, and any findings will provide technical support for water pollution control and protection for aquatic environments and can be applied to ecological restoration strategies.

Research on the impacts of sluices and dams on water quality and quantity has experienced two major phases. (1) From the 1960 s to 1990 s, research focused on material and energy transmission, channel structure, and impacts on indicator organism populations. (2) Many experts and scholars had more profound understanding of the management of sluice and dam regulations and demanded that it played more active roles in water quality and quantity and could be used to prevent negative effects on water environment (Zuo et al. 2011).

The main methods used to assess the impacts of sluices and dams on river quality can be classified into four categories. (1) Analysis of aquatic organisms, water quality, water quantity, ecology, and other aspects of the water environment is conducted through field surveys (Muñoz et al. 2005; Mallik and Richardson 2009; Zhao et al. 2010); (2) exploration of the impacts of sluices and dams on river discharge, water quality, ecology, river structure, and other aspects of the water environment has been conducted through examination of historical data (Brandt 2000; Petts and Gurnell 2005; Gülbahar and Elhatip 2005; Kurunc et al. 2006; William 2006; Braatne et al. 2008); and (3) numerical simulation models, including mature hydrological models (such as the Solid and Water Assessment Tool (SWAT)) coupled with water quality models, mature water quality simulation models (such as the water quality analysis simulation program (WASP)), and other numerical simulation analyses have been used (Campbell et al. 2001; Newham et al. 2002; Chung et al. 2008; Marcé et al. 2010). Specifically, mature hydrological models, coupled with water quality models, have been used to analyze the impacts of discharged sewage on downstream water quality (Hayes et al. 1998; Li and Zuo 2012; Zheng et al. 2012; Zhang et al. 2010, 2011, 2013); mature water quality simulation models have been used to calculate and analyze water quality and other aspects of the water environment (Di Toro et al. 1983; Stow et al. 2003; Jae 2010; Zheng et al. 2010; Lai et al. 2013); and (4) mechanism experiments have been carried out. Some researchers have carried out model experiments to analyze the impacts of sluice regulation on flow regimes, migration, and pollutant transformation (Zhang et al. 2012), while others have conducted field experiments to study the change laws of water and sediment contaminants under different regulation conditions (Liu et al. 2011; Chen et al. 2014).

However, in these studies, water quality parameters changed frequently in response to the impacts of sluice regulation; therefore, the influence of sluice and dam regulation on water quality variation was difficult to prove completely by numerical simulation. Mechanism experiments, especially field prototypes for experimental research, need to be further strengthened. Furthermore, experimental research and field monitoring provide the basis for theoretical analyses and numerical simulations. Thus, to better understand and grasp contaminant distribution patterns and processes governing contaminant concentrations in regulated rivers, field research should be applied to water quality processes regulated by sluices. 
Most rivers of the Huai River Basin are fragmented into many short reaches by sluices and dams. Regulation by sluices and dams plays an important role in managing pollution of existing rivers. Research that employs mechanism experiments is helpful in understanding changes and migration processes of water pollutants under the control of sluices and dams, so it is important to continue to carry out mechanism experiments. In this study, we carried out three integrated impact field mechanism experiments on the water quality of a polluted river. The following are the main objectives of our research: (1) the exploration of the change laws and migration processes of water pollutants under different regulation conditions of the Huaidian Sluice using field experiments, (2) the analysis of the impacts of sluice regulation on water quality, and (3) the exploration of the relationships between flow discharges through sluices and changes in pollutant concentrations. The results are expected to provide an experimental basis for further research on the construction of models for aquatic environments, the law of function of gate, and the development of reasonable regulations on water quality and quantity.

\section{Methods and materials}

Study area

The Huai River Basin $\left(30^{\circ} 55^{\prime}-36^{\circ} 36^{\prime} \mathrm{N}, 111^{\circ} 55^{\prime}-\right.$ $121^{\circ} 25^{\prime} \mathrm{E}$ ) is located in eastern China, between the Yangtze River Basin and the Yellow River Basin. It is the sixth largest river basin in China and has many tributaries. The Shaying River is the largest and most seriously polluted tributary of the Huai River Basin and has numerous sluices and dams. The wastewater and chemical oxygen demand (COD) loading rates accounted for over $40 \%$ of that of the main stream of the Huai River; the Shaying River is therefore called the "barometer" of water quality for the Huai River (Zhang et al. 2007).

The Huaidian Sluice $\left(33^{\circ} 23^{\prime} 15^{\prime \prime} \mathrm{N}, 115^{\circ} 04^{\prime} 24^{\prime \prime} \mathrm{E}\right)$ of the Shaying River, located in Shenqiu County, in the city of Zhoukou, Henan, is about $34 \mathrm{~km}$ away from the border of the provinces of Henan and Anhui. The size of its controlled basin area is about $28,150 \mathrm{~km}^{2}$. The Huaidian Sluice is composed of shallow-hole gates, deep-hole gates, and a ship lock. The shallow-hole gate was built in 1959 and has 18 holes; the width of each hole is $6 \mathrm{~m}$. The deep-hole gate was built in 1969 and has five holes, with a width of $10 \mathrm{~m}$ each. Presently, the shallow-hole gate maintains flow discharge, the deep-hole gate is only used in flood periods, and the ship lock is used for normal navigation. The designed flood frequency of the shallow-hole gate and the deep-hole gate is 20 years $\left(3200 \mathrm{~m}^{3} \mathrm{~s}\right)$, and the checking flood frequency is 200 years $\left(3500 \mathrm{~m}^{3} \mathrm{~s}\right)$. The designated irrigation area is about $667 \mathrm{~km}^{2}$, the normal irrigation water level is about $38.50-39.50 \mathrm{~m}$, the highest irrigation water level is $40.00 \mathrm{~m}$, the normal water storage capacity is about $30-37$ million cubic meters, and the maximum storage capacity is about 45 million cubic meters. The study area and locations are shown in Fig. 1.

\section{Experimental design}

To research the impacts of sluice regulation on water quality, three field experiments (experiment A, experiment B, and experiment C) were carried out in March 3rd to 6th, 2010, October 7th to 11th, 2010, and April 5th to 8th, 2013, respectively. Experiment A monitored the spatial distribution of pollutant concentrations of water bodies and sediments under three scheduling modes. Experiment $\mathrm{B}$ monitored the changes in pollution loads of water bodies under four scheduling modes. Experiment $\mathrm{C}$ monitored the spatial and temporal distribution of water quality parameters and transformation laws of pollutants in water, suspended solids, and sediments under five scheduling modes. The overall objective of the three experiments was to study the impacts of sluice regulation on water quality by designing different sluice regulation schedules, monitoring sections, and sampling points in the sluice upstream and downstream.

In experiment $\mathrm{A}$, there were six monitoring sections (I, II, III, IV, V, and VII) upstream and downstream of the sluice and 12 monitoring points $\left(1^{\#}\right.$, $2^{\#}, 3^{\#}, 4^{\#}, 5^{\#}, 6^{\#}, 7^{\#}, 8^{\#}, 9^{\#}, 10^{\#}, 11^{\#}$, and $\left.15^{\#}\right)$, as shown in Fig. 2a; systematic sampling was conducted three times, and supplementary sampling three times; a total of 39 water samples and three sediment samples were collected. In experiment B, there were seven monitoring sections (I, II, III, IV, 


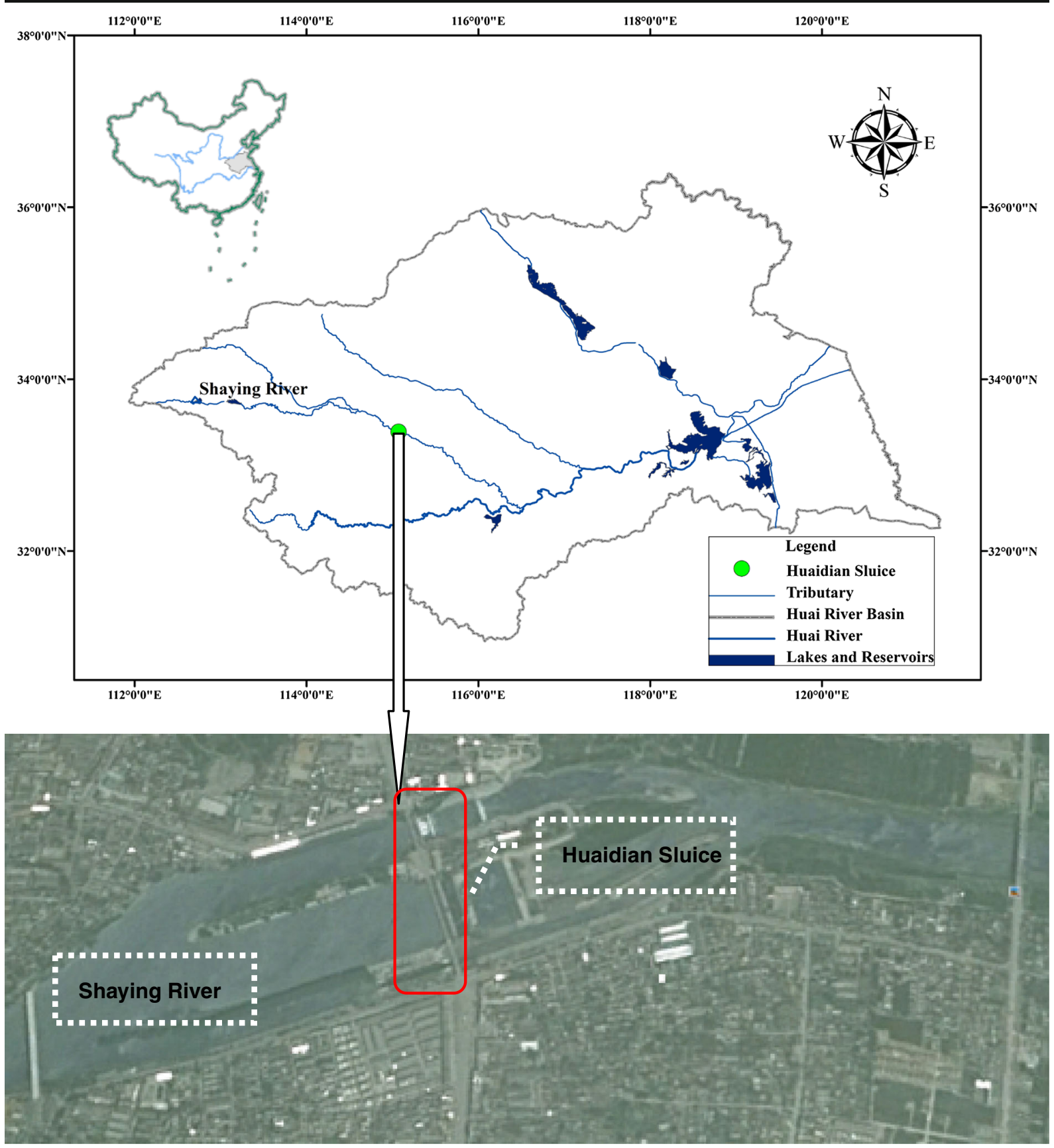

Fig. 1 Map of the study area

$\mathrm{V}, \mathrm{VI}$, and VII) and 15 monitoring points $\left(1^{\#}, 2^{\#}, 3^{\#}\right.$, $4^{\#}, 5^{\#}, 6^{\#}, 7^{\#}, 8^{\#}, 9^{\#}, 10^{\#}, 11^{\#}, 12^{\#}, 13^{\#}, 14^{\#}$, and $15^{\#}$ ), as shown in Fig. 2b; systematic sampling was conducted five times and supplementary sampling four times; a total of 99 water samples were collected. In experiment $\mathrm{C}$, there were five monitoring sections (I, III, IV, V, and VII) and five monitoring points $\left(1^{\#}, 5^{\#}, 7^{\#}, 12^{\#}\right.$, and $\left.15^{\#}\right)$, as shown in Fig. 2c; systematic sampling was conducted seven times; a total of 18 water samples, three sediment samples, and four upper cover water samples were collected. To further analyze trends in pollutant concentrations in each monitoring cross section under different scheduling modes, four representative 
monitoring cross sections were selected as follows: the main stream upstream of the sluice (I), the cross section near the shallow-hole upstream of the sluice
(IV), the end of the baffle wall style downstream of the sluice $(\mathrm{V})$, and the mainstream downstream of the sluice (VII).
Fig. 2 Sampling cross sections and points layout diagram in the field experiments: a experiment $\mathrm{A}, \mathbf{b}$ experiment $\mathrm{B}$, and $\mathbf{c}$ experiment $\mathrm{C}$
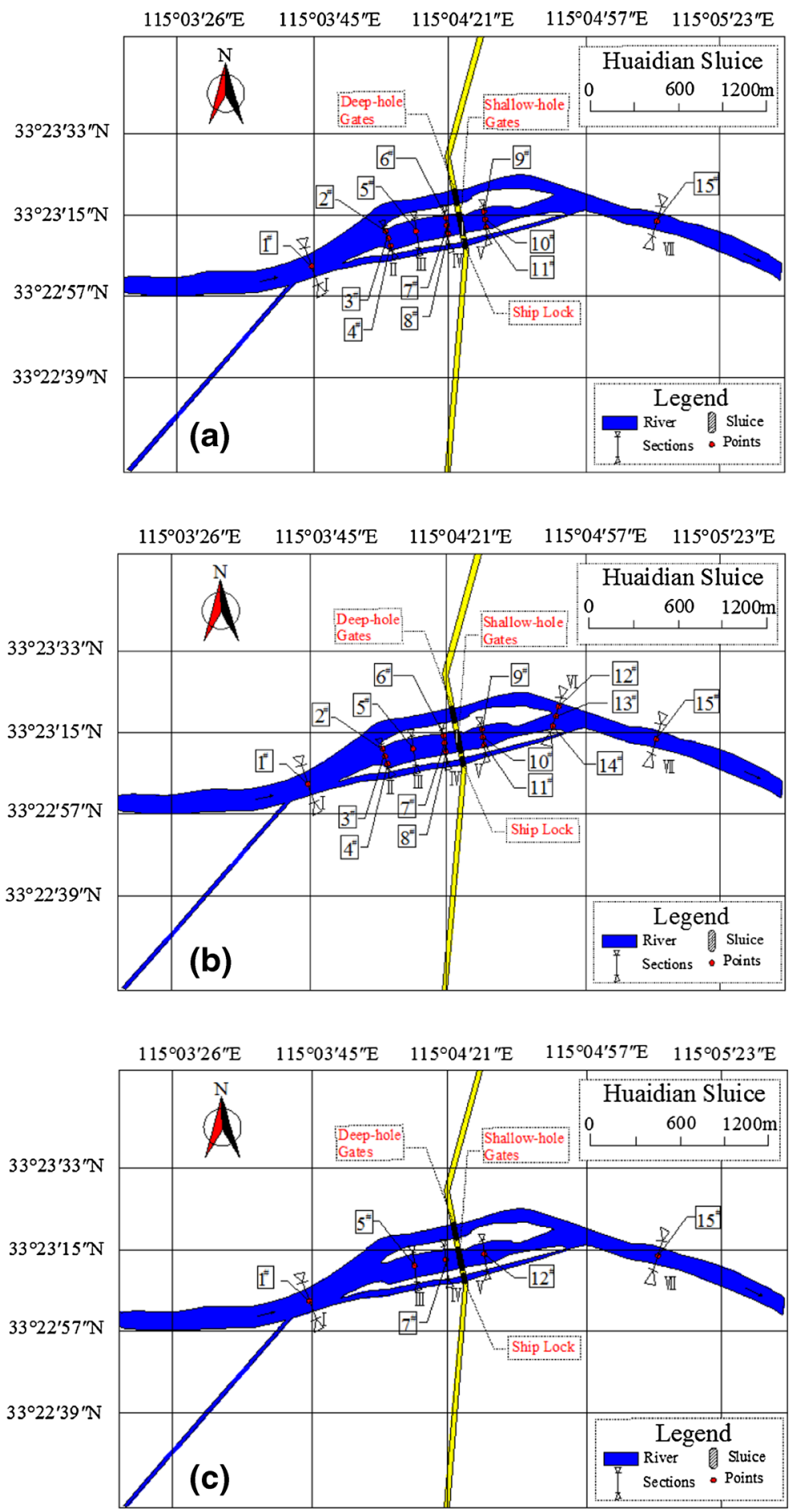
Research methods

\section{Monitoring and sampling processes}

The sampling and monitoring methods of experiment A were divided into three steps. (1) Sampling and monitoring of water and sediments were conducted in current scheduling mode (all 18 shallow-hole gates opened $20 \mathrm{~cm}$ ), (2) sampling and monitoring of water were conducted in decreased gate opening mode (all 18 shallow-hole gates opened $10 \mathrm{~cm}$ ), and (3) sampling and monitoring of water were conducted in increased gate opening mode (all 18 shallow-hole gates opened $50 \mathrm{~cm}$ ). Experimental monitoring indicators were divided into field monitoring indicators (temperature, flow velocity, and water depth) and indoor detection indexes (ammonia nitrogen $\left(\mathrm{NH}_{4}-\mathrm{N}\right.$ ) and permanganate index $\left.\left(\mathrm{COD}_{\mathrm{Mn}}\right)\right)$.

Experiment B was set three floodgate scheduling modes. (1) Sampling and monitoring of water was conducted in the current scheduling mode (all 18 shallowhole gates opened $20 \mathrm{~cm}$ and 12 deep-hole gates opened $50 \mathrm{~cm}$ ), (2) sampling and monitoring experiments of water were conducted in the centralized small opening mode (10 middle shallow-hole gates opened $40 \mathrm{~cm}$, and the deep-hole gates closed) and the centralized large opening mode (10 middle shallow-hole gates opened $80 \mathrm{~cm}$ and the deep-hole gates closed), (3) sampling and monitoring of water were conducted in the large opening mode (all 18 shallow-hole gates opened $80 \mathrm{~cm}$ and the deep-hole gates closed) and small opening mode (all 18 shallow-hole gates opened $40 \mathrm{~cm}$ and the deep-hole gates closed). Experimental monitoring indicators were divided into field monitoring indicators (temperature, flow velocity, and water depth) and indoor detection indexes $\left(\mathrm{NH}_{4}-\mathrm{N}\right.$ and $\left.\mathrm{COD}_{\mathrm{Mn}}\right)$.

Experiment $\mathrm{C}$ included three scheduling modes, and the numbers of open gates and the widths of gate openings were different in each scheduling mode. (1) The sampling and monitoring of water, suspended solids, and sediment were conducted in current scheduling mode (the middle eight shallow-hole gates opened $30 \mathrm{~cm})$, (2) the sampling and monitoring of water and suspended solids were conducted in large gate opening mode (the middle six shallow-hole gates opened $50 \mathrm{~cm}$ and middle four shallow-hole gates opened $70 \mathrm{~cm}$ ), and (3) the sampling and monitoring of water and suspended solids were conducted in decreased gate opening mode (middle four shallow-hole gates opened $10 \mathrm{~cm}$ and all shallow-hole gates closed). Experimental monitoring indicators were divided into field monitoring indicators (temperature, flow velocity, and water depth) and indoor detection indexes $\left(\mathrm{NH}_{4}-\mathrm{N}, \mathrm{COD}_{\mathrm{Mn}}\right.$, biochemical oxygen demand $\left(\mathrm{BOD}_{5}\right)$, nitrate nitrogen, and suspended solids).

\section{Experimental apparatus and methods}

The following equipment was used: $\mathrm{pH}$ meter (PHS25), turbidity meter (WGZ-B), intelligent velocity meter (LGY-II), portable ultrasonic depth meter (HSW-1000 DIG), thermometer, portable ammonia analyzer (PC-II), $\mathrm{HACH}$ water quality monitoring component, Hydrolab DS5 instrument, homemade sediment grab sampler, and homemade suspended solids sampler.

Surface water samples were taken in polyethylene bottles, with sampling depths of $0-0.2 \mathrm{~m}$; surface sediment samples were collected with the grab sampler in experiments $\mathrm{A}$ and $\mathrm{C}$, with sampling depths of 0 $0.15 \mathrm{~m}$; suspended solids samples were collected with the homemade sampling device in experiment $\mathrm{C}$, with sampling depths of about $0.15 \mathrm{~m}$. All samples were sealed in plastic bags or polyethylene bottles and were sent to the technical laboratory for analysis. The analysis followed the methodology provided in "Water and Wastewater Monitoring Analysis Method" (SEPA 2002) and "Regulation for Water Environmental Monitoring" (Yangtze River Basin Water Environment Monitoring Center 1998).

$\mathrm{NH}_{4}-\mathrm{N}$ and $\mathrm{COD}_{\mathrm{Mn}}$ concentrations were analyzed in different scheduling modes; then, flow discharges through the Huaidian Sluice were measured under various scheduling modes for $\mathrm{NH}_{4}-\mathrm{N}$ and $\mathrm{COD}_{\mathrm{Mn}}$ indexes in the three experiments, and change laws under different flow rates were explored, and appropriate flow discharges (or sluice scheduling modes) through sluices were analyzed and achieved.

\section{Mathematics model}

WASP is one of the most widely used water quality models in the world, which can be applied in one-, two-, and three-dimensional aquatic systems, such as lakes, ponds, streams, rivers, reservoirs, estuaries, and coastal waters, and developed by the Athens laboratory of the EPA (Wool et al. 2001). The WASP7.5 system consists of two independent computer programs, DYNHYD5 and WASP. The hydrodynamics program, 
DYNHYD5, is used to simulate the movement of water, while the water quality program, WASP, is used to simulate the movement and interaction of pollutants in water. The WASP program also includes the EUTRO and TOXI models. The WASP7.5 is supplied with the abovementioned sub-models to simulate two major classes of water quality problems: conventional pollution and toxic pollution. The former, which includes dissolved oxygen, $\mathrm{BOD}_{5}$, phosphorus, and nitrogen, are addressed using the EUTRO sub-model; the latter, which includes organic chemicals, metals and sediment, is addressed by the TOXI sub-model (Wool et al. 2001).This model allows users to interpret and predict water quality responses to natural phenomena and man-made pollution caused by various pollution management decisions, and it can simulate hydrological dynamics, unsteady flow in one-dimensional rivers, unsteady threedimensional flow in lakes and estuaries, and the migration and transformation rules of conventional pollution and toxic pollution of water.

In this study, we wanted to simulate the impacts of flow rates on water pollutant concentration changes under different scenarios and considered the influence of sediment pollutants. WASP software can satisfy the simulation requirements. Thus, WASP was selected as the mathematics model to simulate water quality changes. According to the field conditions of the Huaidian Sluice, the sluice-controlled river was divided into two sections: the section upstream and the section downstream of the sluice. Analog ideas were as follows: first, to verify the reliability of the model in combination with field monitoring data, the concentrations of two monitoring indicators, $\mathrm{NH}_{4}-\mathrm{N}$ and $\mathrm{COD}$, were simulated upstream of the sluice using the simulation software WASP7.5; then, the simulation results were used as initial pollution values downstream of the sluice to analyze the impacts of sluice regulation on water quality under different scenarios or at different flow rates.

\section{Results}

Experimental results

In this paper, different water quality indicators were detected in three field experiments on the Huaidian Sluice; we summarized the water monitoring results obtained from them, as well as results from other research conducted nationally and internationally. Two common indicators $\left(\mathrm{COD}_{\mathrm{Mn}}\right.$ and $\left.\mathrm{NH}_{4}-\mathrm{N}\right)$ were chosen to research the impacts of sluice regulation on water quality. In the current scheduling mode of experiment B, deep-hole gates were turned on, while only shallowhole gates were open in the other scheduling modes. $\mathrm{COD}_{\mathrm{Mn}}$ and $\mathrm{NH}_{4}-\mathrm{N}$ concentrations measured in different scheduling modes were shown in Table 1; variations in pollutant concentrations in different sections and under different regulation modes are shown in Fig. 3.

$\mathrm{COD}_{\mathrm{Mn}}$ concentrations were quite different between different scheduling modes. Under most scheduling conditions in experiments $\mathrm{A}$ and $\mathrm{B}, \mathrm{COD}_{\mathrm{Mn}}$ concentration declined continuously upstream of the gates, reached a minimum value near the gates, then increased downstream of the gates to the end cross section of the baffle wall style, and gradually decreased again upstream of the hydrological station cross section. However, there were three regulation modes (all 18 shallowhole gates opened $10 \mathrm{~cm}$ and all 18 shallow-hole gates opened $50 \mathrm{~cm}$ of experiment A, and 10 middle shallowhole gates opened $40 \mathrm{~cm}$ of experiment $\mathrm{B}$ ) in which this pattern was not observed. $\mathrm{COD}_{\mathrm{Mn}}$ and $\mathrm{NH}_{4}-\mathrm{N}$ concentrations were consistent between most scheduling modes of experiment $\mathrm{C}$, except the scheduling mode in which the middle four shallow-hole gates were opened $70 \mathrm{~cm}$; these concentrations were also similar to those observed in experiment $\mathrm{B}$ in the scheduling mode in which 10 middle shallow-hole gates were opened $40 \mathrm{~cm}$.

$\mathrm{NH}_{4}-\mathrm{N}$ concentrations were also quite different between different scheduling modes. In most scheduling modes (about $46.2 \%$ of scheduling modes), $\mathrm{NH}_{4}-\mathrm{N}$ concentrations in water increased continually upstream of the gates, then declined downstream of the gates to the end cross section of the baffle wall style, and gradually increased again upstream of the cross section of the hydrological station. In about $23.1 \%$ of scheduling modes, pollutant concentrations decreased continually upstream of the gates, reached a minimum near the gates, increased downstream of the gates to the end cross section of the baffle wall style, and then gradually decreased again upstream of the cross section of the hydrological station. In the remaining scheduling modes, irregular results were observed.

In about $38.5 \%$ of scheduling modes, trends of $\mathrm{COD}_{\mathrm{Mn}}$ and $\mathrm{NH}_{4}-\mathrm{N}$ concentrations were opposite to one another; in about $15.4 \%$ of scheduling modes, concentrations follow the same trends; in the remaining scheduling modes, concentrations were 
Table 1 Experimental results of water quality indicators

\begin{tabular}{|c|c|c|c|c|c|}
\hline \multirow[t]{2}{*}{ Experiment number } & \multirow[t]{2}{*}{ Regulation modes } & \multirow{2}{*}{$\begin{array}{l}\text { Monitoring } \\
\text { points }\end{array}$} & \multirow{2}{*}{$\begin{array}{l}\text { Water flow } \\
\left(\mathrm{m}^{3} / \mathrm{s}\right)\end{array}$} & \multicolumn{2}{|c|}{ Monitoring indicators concentrations $(\mathrm{mg} / \mathrm{L})$} \\
\hline & & & & $\mathrm{COD}_{\mathrm{Mn}}$ & $\mathrm{NH}_{4}-\mathrm{N}$ \\
\hline \multirow[t]{12}{*}{ Experiment A } & \multirow[t]{4}{*}{18 holes $20 \mathrm{~cm}$} & $1^{\#}$ & \multirow[t]{4}{*}{78} & 5.48 & 4.42 \\
\hline & & $7^{\#}$ & & 4.94 & 4.85 \\
\hline & & $10^{\#}$ & & 5.51 & 4.66 \\
\hline & & $15^{\#}$ & & 5.30 & 4.83 \\
\hline & \multirow[t]{4}{*}{18 holes $10 \mathrm{~cm}$} & $1^{\#}$ & \multirow[t]{4}{*}{39} & 5.58 & 4.17 \\
\hline & & $7^{\#}$ & & 5.52 & 4.23 \\
\hline & & $10^{\#}$ & & 5.25 & 4.15 \\
\hline & & $15^{\#}$ & & 5.13 & 4.85 \\
\hline & \multirow[t]{4}{*}{18 holes $50 \mathrm{~cm}$} & $1^{\#}$ & \multirow[t]{4}{*}{187} & 5.47 & 4.26 \\
\hline & & $7^{\#}$ & & 5.62 & 4.24 \\
\hline & & $10^{\#}$ & & 5.08 & 4.04 \\
\hline & & $15^{\#}$ & & 4.97 & 4.79 \\
\hline \multirow[t]{20}{*}{ Experiment B } & \multirow{4}{*}{$\begin{array}{l}\text { Shallow-hole gate } \\
18 \text { holes } 20 \mathrm{~cm} \text {, } \\
\text { deep-hole gate } 5 \\
\text { holes } 50 \mathrm{~cm}\end{array}$} & $1^{\#}$ & \multirow[t]{4}{*}{60} & 3.34 & 0.12 \\
\hline & & $7^{\#}$ & & 3.07 & 0.15 \\
\hline & & $10^{\#}$ & & 3.34 & 0.16 \\
\hline & & $15^{\#}$ & & 3.02 & 0.14 \\
\hline & \multirow[t]{4}{*}{10 holes $40 \mathrm{~cm}$} & $1^{\#}$ & \multirow[t]{4}{*}{65} & 3.40 & 0.16 \\
\hline & & $7^{\#}$ & & 3.49 & 0.11 \\
\hline & & $10^{\#}$ & & 3.38 & 0.12 \\
\hline & & $15^{\#}$ & & 3.51 & 0.12 \\
\hline & \multirow[t]{4}{*}{10 holes $80 \mathrm{~cm}$} & $1^{\#}$ & \multirow[t]{4}{*}{125} & 3.50 & 0.14 \\
\hline & & $7^{\#}$ & & 3.38 & 0.18 \\
\hline & & $10^{\#}$ & & 3.46 & 0.15 \\
\hline & & $15^{\#}$ & & 3.32 & 0.16 \\
\hline & \multirow[t]{4}{*}{18 holes $80 \mathrm{~cm}$} & $1^{\#}$ & \multirow[t]{4}{*}{226} & 3.42 & 0.28 \\
\hline & & $7^{\#}$ & & 3.37 & 0.27 \\
\hline & & $10^{\#}$ & & 3.50 & 0.30 \\
\hline & & $15^{\#}$ & & 3.37 & 0.30 \\
\hline & \multirow[t]{4}{*}{18 holes $40 \mathrm{~cm}$} & $1^{\#}$ & \multirow[t]{4}{*}{117} & 3.32 & 0.26 \\
\hline & & $7^{\#}$ & & 3.23 & 0.27 \\
\hline & & $10^{\#}$ & & 3.36 & 0.27 \\
\hline & & $15^{\#}$ & & 3.25 & 0.29 \\
\hline \multirow[t]{11}{*}{ Experiment $\mathrm{C}$} & 8 holes $30 \mathrm{~cm}$ & $1^{\#}$ & 63 & 4.78 & 2.50 \\
\hline & & $7^{\#}$ & & 5.47 & 2.54 \\
\hline & & $12^{\#}$ & & 5.11 & 2.20 \\
\hline & & $15^{\#}$ & & 5.25 & 2.60 \\
\hline & 6 holes $50 \mathrm{~cm}$ & $1^{\#}$ & 72 & 5.35 & 2.55 \\
\hline & & $7^{\#}$ & & 5.36 & 2.44 \\
\hline & & $12^{\#}$ & & 4.64 & 3.30 \\
\hline & & $15^{\#}$ & & 5.15 & 2.56 \\
\hline & 4 holes $70 \mathrm{~cm}$ & $1^{\#}$ & 55 & 4.69 & 2.58 \\
\hline & & $7^{\#}$ & & 4.16 & 2.81 \\
\hline & & $12^{\#}$ & & 4.87 & 2.45 \\
\hline
\end{tabular}


Table 1 (continued)

\begin{tabular}{|c|c|c|c|c|c|}
\hline \multirow[t]{2}{*}{ Experiment number } & \multirow[t]{2}{*}{ Regulation modes } & \multirow{2}{*}{$\begin{array}{l}\text { Monitoring } \\
\text { points }\end{array}$} & \multirow{2}{*}{$\begin{array}{l}\text { Water flow } \\
\left(\mathrm{m}^{3} / \mathrm{s}\right)\end{array}$} & \multicolumn{2}{|c|}{ Monitoring indicators concentrations $(\mathrm{mg} / \mathrm{L})$} \\
\hline & & & & $\mathrm{COD}_{\mathrm{Mn}}$ & $\mathrm{NH}_{4}-\mathrm{N}$ \\
\hline & & $15^{\#}$ & & 4.26 & 2.63 \\
\hline & 4 holes $10 \mathrm{~cm}$ & $1^{\#}$ & 14 & 4.88 & 3.19 \\
\hline & & $7^{\#}$ & & 4.94 & 2.96 \\
\hline & & $12^{\#}$ & & 3.46 & 1.45 \\
\hline & & $15^{\#}$ & & 4.63 & 2.70 \\
\hline & 0 holes $0 \mathrm{~cm}$ & $1^{\#}$ & 0 & 2.05 & 1.95 \\
\hline & & $7^{\#}$ & & 4.83 & 2.85 \\
\hline & & $12^{\#}$ & & 3.93 & 2.40 \\
\hline & & $15^{\#}$ & & 4.60 & 2.79 \\
\hline
\end{tabular}

irregular. $\mathrm{COD}_{\mathrm{Mn}}$ and $\mathrm{NH}_{4}-\mathrm{N}$ concentrations observed in experiment $\mathrm{A}$ were higher than in the other experiments, while concentrations observed in experiment B were lower than in the other experiments.

\section{Scenario analysis}

\section{Model calibration}

In the scheduling mode of experiment $\mathrm{C}$ in which eight gates were opened $30 \mathrm{~cm}, \mathrm{NH}_{4}-\mathrm{N}$ and $\mathrm{COD}$ concentrations were simulated using the EUTRO module of WASP7.5. Combined with the simulation needs, the Euler method was used. One-dimensional kinematic wave theory was selected for the simulation of water dynamics, model defaults were used as adjustment coefficients of maximum and minimum time steps, and the time was used for calibration from 16:53 on April 5th, 2013, to 8:02 on April 6th, 2013. Based on the field experimental conditions, upstream and downstream of sluice were divided into two parts, and the unit body model data of initial moments were input. Simulation results of $\mathrm{NH}_{4}-\mathrm{N}$ and COD concentrations in the upper reach of the sluice were verified. Numerical simulation and field experiment results are compared in Table 2 and Fig. 4.

As shown in Table 2 and Fig. 4, the relative errors of all five time points were within $10.0 \%$. Thus, the simulation results were reasonable and could be used as the inputs for the simulation of the river downstream of the sluice.

\section{Numerical simulation results of the river downstream} of the sluice

According to the conditions present in the river downstream of the sluice, model segment portions were set, the simulation time was from 16:53 on April 5th to $12: 18$ on April 8th, 2013, and the other parameters remained the same. $\mathrm{NH}_{4}-\mathrm{N}$ and COD simulations were carried out to analyze pollutant concentration changes under different flow conditions (different gate openings). Simulated concentrations were plotted over time under different flow conditions, as shown in Fig. 5.

As shown in Fig. 5a, the $\mathrm{NH}_{4}-\mathrm{N}$ concentration initially increased, then decreased under all the flow conditions, except for at a flow of $10 \mathrm{~m}^{3} \mathrm{~s}$; as the flow increased, the magnitudes of both the increases and decreases in $\mathrm{NH}_{4}-\mathrm{N}$ concentrations were somewhat magnified. Under a flow of $10 \mathrm{~m}^{3} \mathrm{~s}$, trends in $\mathrm{NH}_{4}-\mathrm{N}$ concentrations were different; a sharp decrease occurred initially, followed by a sharp increase soon afterwards, then a slow decline.

As shown in Fig. 5b, the simulated COD concentration initially increased, then decreased under a flow of $10 \mathrm{~m}^{3} \mathrm{~s}$. Under other flow conditions, it initially decreased, increased soon afterwards, and then decreased again; at higher flow rates, the initial decrease was lower. At higher flow rates, simulated COD concentrations at the end of the simulation period were lower; however, the difference between simulated COD concentrations at different flow 

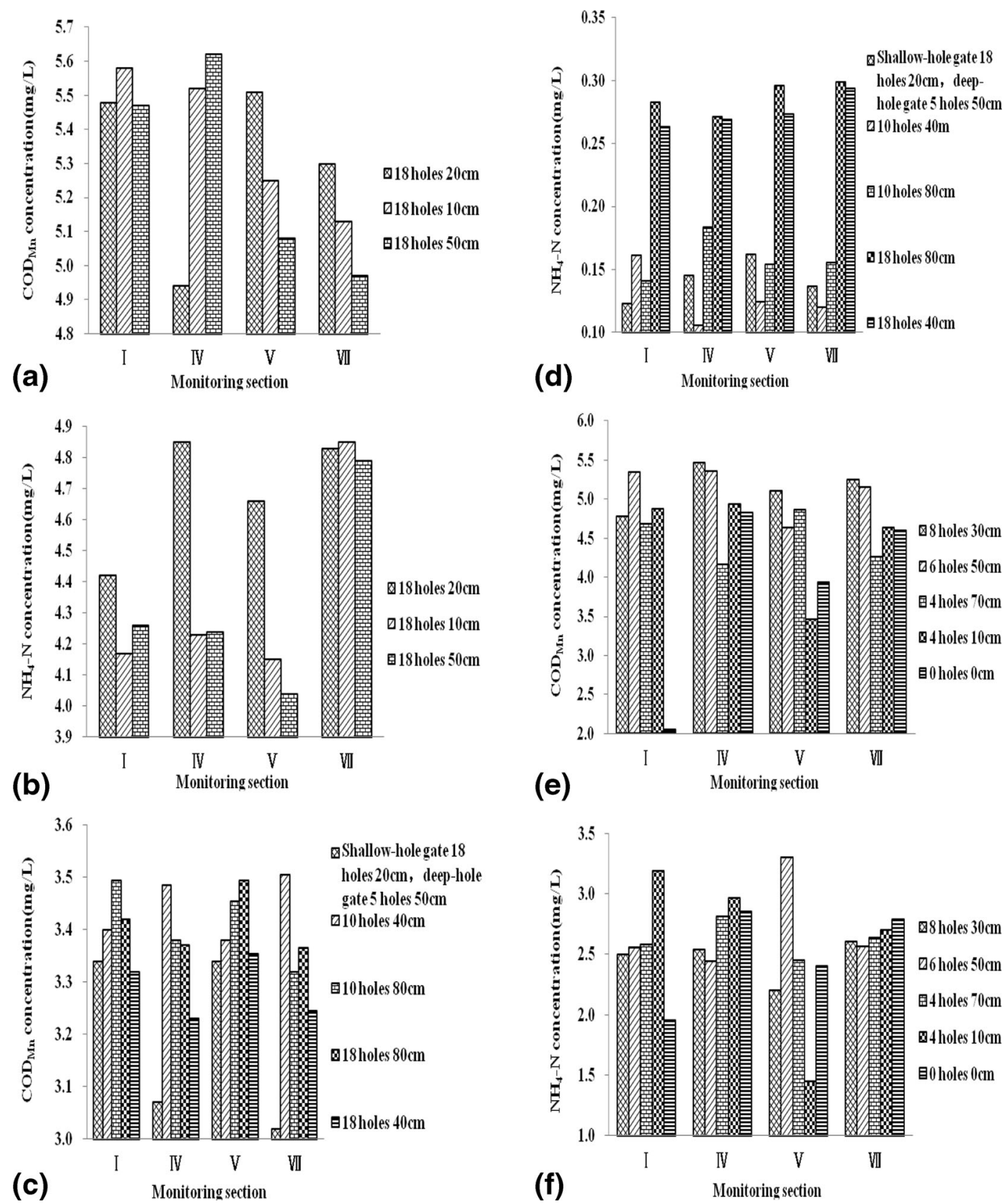

Fig. 3 Pollutant concentrations under different experimental conditions: $\mathbf{a}, \mathbf{b}$ experiment A; $\mathbf{c}, \mathbf{d}$ experiment $\mathrm{B}$; and $\mathbf{e}, \mathbf{f}$ experiment $\mathrm{C}$

periods was minor. For example, when the flow was $10 \mathrm{~m}^{3} \mathrm{~s}$, the simulated COD concentration was $2.668 \mathrm{mg} / \mathrm{L}$, and when the flow was $250 \mathrm{~m}^{3} \mathrm{~s}$, COD simulated concentration was $2.535 \mathrm{mg} / \mathrm{L}$ (a difference of $0.133 \mathrm{mg} / \mathrm{L}$ ).

As shown in Fig. 5, the numerical simulation results of $\mathrm{NH}_{4}-\mathrm{N}$ and $\mathrm{COD}$ concentrations showed opposite trends. The following were the potential causes. The $\mathrm{NH}_{4}-\mathrm{N}$ concentration was far lower than the COD concentration in the sediment; COD would be released from sediment into water when the velocity was low, while $\mathrm{NH}_{4}-\mathrm{N}$ gave priority to static release at that time; water flow played an important role in purifying water body to a certain extent. 
Table 2 Performance of the model with respect to the prediction of $\mathrm{NH}_{4}-\mathrm{N}$ and $\mathrm{COD}$ concentrations in the upper reach of the sluice $(\mathrm{mg} / \mathrm{L})$

\begin{tabular}{llll}
\hline $\begin{array}{l}\text { Monitoring } \\
\text { indicators }\end{array}$ & $\begin{array}{l}\text { Experiment } \\
\text { results }\end{array}$ & $\begin{array}{l}\text { Simulation } \\
\text { results }\end{array}$ & $\begin{array}{l}\text { Relative } \\
\text { error (\%) }\end{array}$ \\
\hline $\mathrm{NH}_{4} \mathrm{-N}$ & 2.54 & 2.56 & 0.8 \\
& 2.56 & 2.53 & 1.2 \\
& 2.54 & 2.47 & 2.8 \\
& 2.45 & 2.34 & 4.5 \\
$\mathrm{COD}$ & 2.35 & 2.30 & 2.1 \\
& 5.47 & 4.98 & 9.0 \\
& 5.32 & 4.90 & 7.9 \\
& 5.15 & 4.75 & 7.8 \\
& 4.80 & 4.45 & 7.3 \\
& 4.65 & 4.35 & 6.5 \\
\hline
\end{tabular}

Relative error was calculated by the formula: $\left(C_{\text {measured value }}-C_{\text {simulated value }}\right) / C_{\text {measured value }}$

Sluices played an important part in maintaining river ecological health and reducing downstream pollutant concentrations; to do this effectively, for $\mathrm{NH}_{4}-\mathrm{N}$, daily flow discharge through the sluice should be as low as possible, while for COD, daily flow discharge should be greater than $10 \mathrm{~m}^{3} \mathrm{~s}$. Meanwhile, to understand the effects of flow rate within $10-50 \mathrm{~m}^{3} \mathrm{~s}$ on water pollution, COD concentrations were simulated under three flow rates: 20, 30, and $40 \mathrm{~m}^{3} \mathrm{~s}$; the results were shown in Fig. 6. The simulated COD concentrations under the three flow rates were the same as those under a flow rate of $50 \mathrm{~m}^{3} \mathrm{~s}$.

\section{Discussion}

Water quality monitoring results

According to Chinese Environmental quality standards for surface water (GB 3838-2002) (China State Environmental Protection Administration 2002), the specific standard values were shown in Table $3 . \mathrm{COD}_{\mathrm{Mn}}$ belonged to class III, and $\mathrm{NH}_{4}-\mathrm{N}$ belonged to below class $\mathrm{V}$ in experiment $\mathrm{A}$. In experiment $\mathrm{B}, \mathrm{COD}_{\mathrm{Mn}}$ belonged to class II, and $\mathrm{NH}_{4}-\mathrm{N}$ belonged to classes I and II. In experiment $\mathrm{C}, \mathrm{COD}_{\mathrm{Mn}}$ belonged to classes II and III; $\mathrm{NH}_{4}-\mathrm{N}$ belonged to class IV and below class V water quality standards. Meanwhile, the monitoring
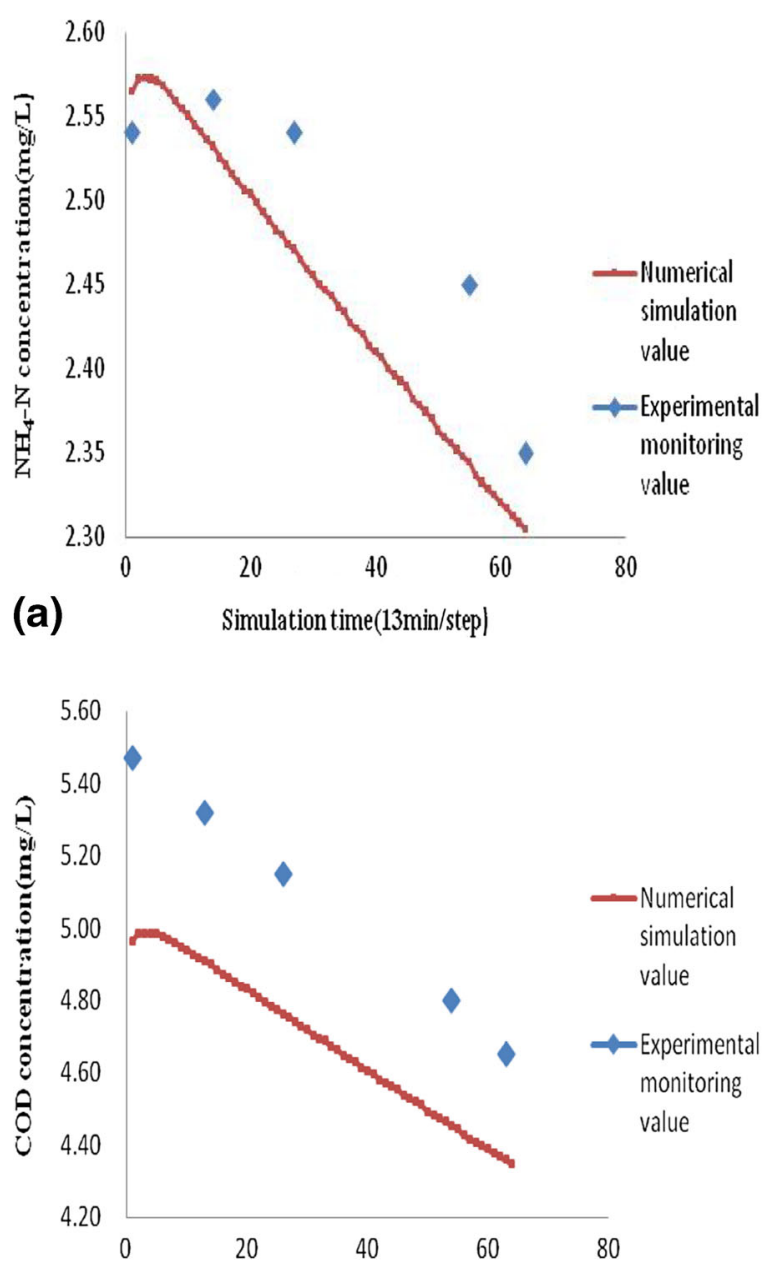

(b) Simulationtime(13min/step)

Fig. 4 The relationship between simulated and experimental values in the upper reach of the sluice for $\mathbf{a} \mathrm{NH}_{4}-\mathrm{N}$ and $\mathbf{b} \mathrm{COD}$ concentrations

results demonstrated that the water quality of experiment B was significantly superior to that of experiments $\mathrm{A}$ and $\mathrm{C}$. This might be because experiment $\mathrm{B}$ was conducted at the end of the flood period, so the flow rate was large (about $300 \mathrm{~m}^{3} \mathrm{~s}$, which was about five times higher than that of the other experiments). When the water was clearer, it could have played a role in diluting the pollutants. experiments $\mathrm{A}$ and $\mathrm{C}$ were conducted during the dry season and spring irrigation period, respectively, so upstream inflow was low because of high water consumption; low inflow may lead to pollutant enrichment and degraded water quality.

The numbers of open gates and the width of gate openings were different in each experiment. Combined 


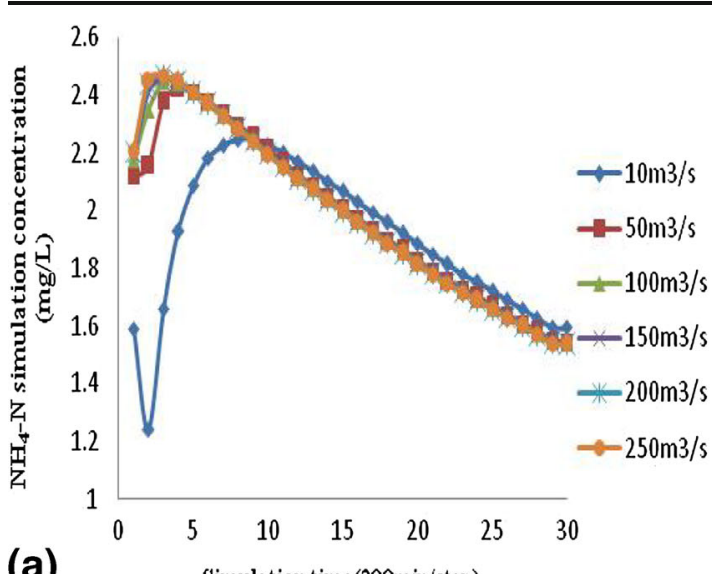

(a) Simulation time(200min/step)

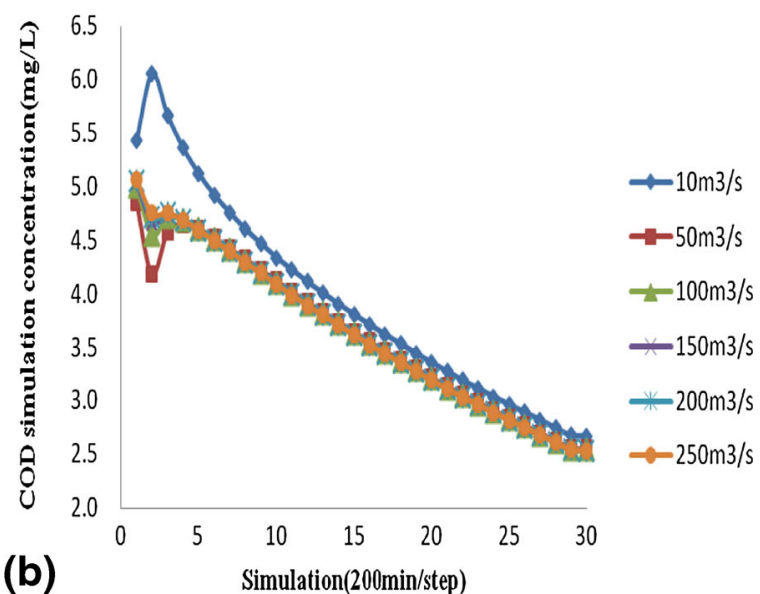

Fig. 5 Simulated pollutant concentration values under different flow conditions for $\mathbf{a} \mathrm{NH}_{4}-\mathrm{N}$ and $\mathbf{b} \mathrm{COD}$

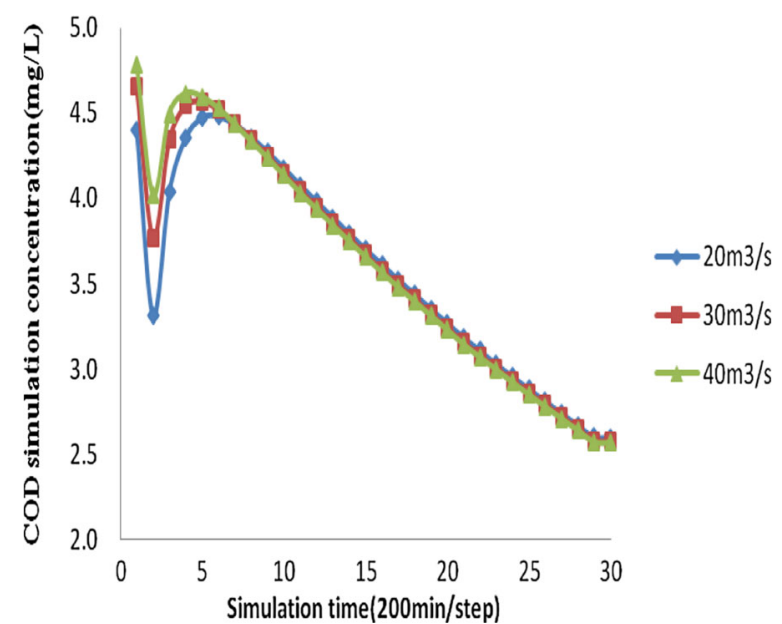

Fig. 6 Simulated COD concentrations under different flow conditions with field monitoring data, flow discharge through the Huaidian Sluice was set under various scheduling modes, and the $\mathrm{COD}_{\mathrm{Mn}}$ and $\mathrm{NH}_{4}-\mathrm{N}$ concentrations of each monitoring cross section in the three experiments and their response to changes in flow rates were plotted (Figs. 7 and 8).

As shown in Fig. 7, When all the gates were closed, i.e., when flow discharge through the sluice was zero, $\mathrm{COD}_{\mathrm{Mn}}$ concentrations in the sections occurred in the following order: $\mathrm{COD}_{\mathrm{Mn}}(\mathrm{I})<\mathrm{COD}_{\mathrm{Mn}}$ (V) $<\mathrm{COD}_{\mathrm{Mn}}$ (VII) $<\mathrm{COD}_{\mathrm{Mn}}$ (IV). Water velocities through upper gates dropped significantly as they were closed, even a reflow phenomenon would occur; thus, a higher amount of pollutants would accumulate, causing degraded water quality; $\mathrm{COD}_{\mathrm{Mn}}$ concentration reached a maximum in section IV. At that time, water flow velocity was greater in cross section I, and a low amount of pollutants accumulated, so the $\mathrm{COD}_{\mathrm{Mn}}$ concentration reached a minimum. Downstream of the sluice, water flow and velocity decreased drastically, so water pollutants accumulated, and pollutant concentrations increased gradually with increasing distance from the sluice. This shows that upstream runoff can promote purification downstream.

With an increase in the width or number of gate openings, compared with cross section I, $\mathrm{COD}_{\mathrm{Mn}}$ concentration of cross section VII decreased under most flow conditions, except for two flow rates (65 and $63 \mathrm{~m}^{3} \mathrm{~s}$ ). For the remaining flow rates, the magnitude of the decrease in concentration between the two sections occurred in the following order: $0.5 \mathrm{mg} / \mathrm{L}$ $\left(187 \mathrm{~m}^{3} \mathrm{~s}\right.$ flow rate $)>0.45 \mathrm{mg} / \mathrm{L}\left(39 \mathrm{~m}^{3} \mathrm{~s}\right.$ flow rate) $>0.43 \mathrm{mg} / \mathrm{L}\left(55 \mathrm{~m}^{3} \mathrm{~s}\right.$ flow rate $)>0.32 \mathrm{mg} / \mathrm{L}$ $\left(60 \mathrm{~m}^{3} \mathrm{~s}\right.$ flow rate $)>0.25 \mathrm{mg} / \mathrm{L}\left(14 \mathrm{~m}^{3} \mathrm{~s}\right.$ flow rate) $>0.20 \mathrm{mg} / \mathrm{L}\left(72 \mathrm{~m}^{3} \mathrm{~s}\right.$ flow rate $)>0.18 \mathrm{mg} / \mathrm{L}$ $\left(78 \mathrm{~m}^{3} \mathrm{~s}\right.$ and $125 \mathrm{~m}^{3} \mathrm{~s}$ flow rate) $>0.07 \mathrm{mg} / \mathrm{L}$ $\left(117 \mathrm{~m}^{3} \mathrm{~s}\right.$ flow rate $)>0.05 \mathrm{mg} / \mathrm{L}\left(226 \mathrm{~m}^{3} \mathrm{~s}\right.$ flow rate $)$. These data indicated that $\mathrm{COD}_{\mathrm{Mn}}$ concentrations were reduced to different extents by different flow discharge rates through the sluice at cross section VII. Sediment disturbance was minimal under low flow conditions, so sediment contaminants were not easily released; low flow could therefore help to promote the degradation of water pollutants. With an increase in flow, however, the intensity of sediment disturbance increased and promoted the release of sediment contaminants. High flow could therefore result in the deterioration of downstream water quality. However, when the impact of flow degradation was greater than that of sediment pollutant 
Table 3 Standard limiting values of surface water environment quality $(\mathrm{mg} / \mathrm{L})$

\begin{tabular}{cllllll}
\hline $\begin{array}{l}\text { Sequence } \\
\text { number }\end{array}$ & Name & $\begin{array}{l}\text { Class } \\
\text { I }\end{array}$ & $\begin{array}{l}\text { Class } \\
\text { II }\end{array}$ & $\begin{array}{l}\text { Class } \\
\text { III }\end{array}$ & $\begin{array}{l}\text { Class } \\
\text { IV }\end{array}$ & $\begin{array}{l}\text { Class } \\
\text { V }\end{array}$ \\
\hline 1 & $\mathrm{COD}_{\mathrm{Mn}} \leq$ & 2 & 4 & 6 & 10 & 15 \\
2 & $\mathrm{NH}_{4}-\mathrm{N} \leq$ & 0.15 & 0.5 & 1.0 & 1.5 & 2.0 \\
\hline
\end{tabular}

release, high flow (e.g., $187 \mathrm{~m}^{3} \mathrm{~s}$ ) could promote a reduction in water pollutants. Considering the role of sluices in storing water, blocking sewage, and supplying water, daily flow of the Huaidian Sluice should not exceed $60 \mathrm{~m}^{3} \mathrm{~s}$, which would not only meet the supply requirements of downstream water consumption but would also purify downstream water to a certain degree.

As shown in Fig. 8, variations in $\mathrm{NH}_{4}-\mathrm{N}$ concentrations in response occurred as follows. (1) When the gates closed, characteristics of the changes in $\mathrm{NH}_{4}-\mathrm{N}$ concentrations followed the same pattern as that ob-

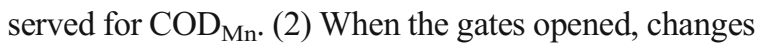
in sluice scheduling had different trends on the abatement or increase of water pollution load. In response to changes in flow, $\mathrm{NH}_{4}-\mathrm{N}$ concentrations in cross section VII were higher than in cross section I in most cases, except for two flow rates (14 and $65 \mathrm{~m}^{3} \mathrm{~s}$ ). Under these flow rates, $\mathrm{NH}_{4}-\mathrm{N}$ concentrations decreased downstream of the sluice by 0.49 and $0.04 \mathrm{mg} / \mathrm{L}$, respectively. Flow discharge rates should therefore be kept low (approximately $14 \mathrm{~m}^{3} \mathrm{~s}$ ).

The impacts of sluice regulation on water quality were inversely proportional to flow discharge rates as presented by Zhang and Zheng (Zhang et al. 2012; Zheng et al. 2012). However, Zhang and Zheng mainly carried out the indoor experiment or numerical simulation, we mainly carried out the field experiments, and the feasible daily flows of Huaidian Sluice were given based on the changes of $\mathrm{COD}_{\mathrm{Mn}}$ and $\mathrm{NH}_{4}-\mathrm{N}$ concentrations, respectively.

Comparison between the monitoring results and numerical simulation results

As shown in Fig. 3, in response to adjustment of the width of gate openings, large differences in water quality occurred in typical reaches, and the trends in pollutant concentrations were different in the same reach in different scheduling modes. Meanwhile, under different flow rates, the trends of water pollutant concentrations

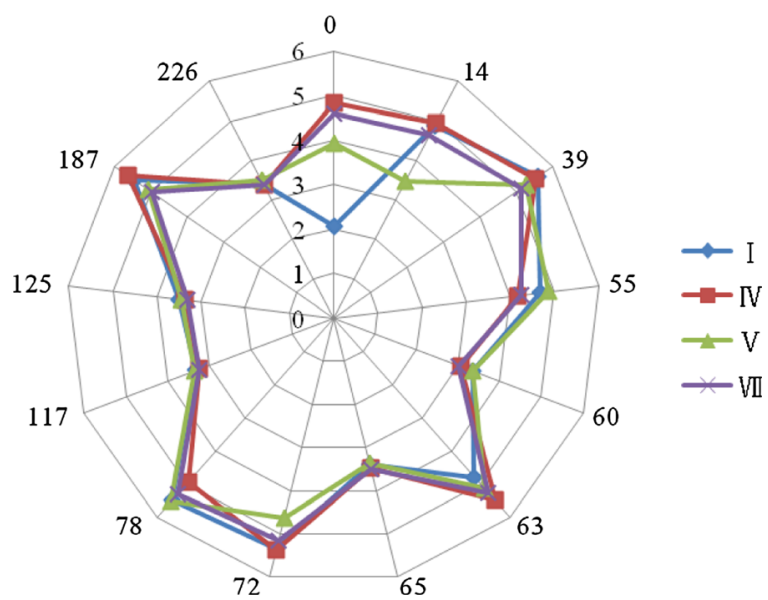

Fig. $7 \mathrm{COD}_{\mathrm{Mn}}$ concentrations in response to different flow rates in different monitoring cross sections

varied. According to Figs. 7 and 8, low flow rates could promote the degradation of water pollutants and promote self-purification of the water body, which is consistent with the water quality simulation results shown in Figs. 5 and 6 . The experimental monitoring results and the numerical simulation results indicate that flow discharge through the sluice should be kept low under normal circumstances, but should be greater than $10 \mathrm{~m}^{3} \mathrm{~s}$. Because water pollutant concentrations are somewhat elevated under high flow conditions, when sluice discharge flow rate is high, the downstream reach should increase its water quality monitoring, and downstream water departments should also be notified to reduce water withdrawal during this period.

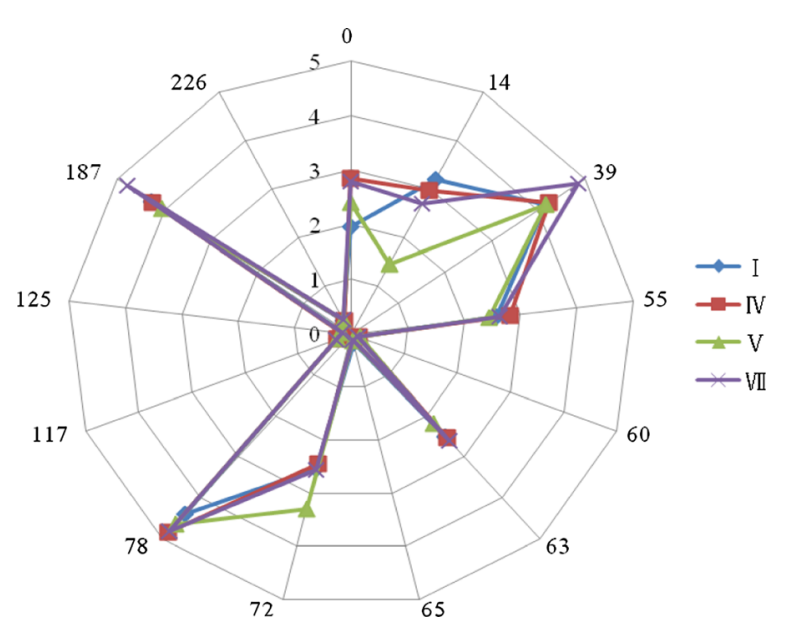

Fig. $8 \mathrm{NH}_{4}-\mathrm{N}$ concentrations in response to different flow rates in different monitoring cross sections 


\section{Conclusions}

Research on the response of water quality under different sluice scheduling modes is a fundamental research topic in river basin management. In this study, we conducted three comprehensive experiments to examine the impact of sluice scheduling on water quality in the Huaidian Sluice of the Shaying River. Flow and water quality indicators of each monitoring cross section were monitored under different scheduling conditions, changes in water quality under different gate opening widths were analyzed, and the effects of flow rates on pollutant concentrations were discussed and compared with the water quality simulation results. The following are our conclusions based on the experimental results and numerical simulation results. (1) As demonstrated by variations in monitoring indicators, water pollution loads downstream of the sluice changed under different scheduling modes. (2) With changes in sluice scheduling, trends in the concentration of pollution indicators varied between monitoring cross sections. (3) The relationships between sluice scheduling and concentrations of water pollution indicators was complex, which demonstrates that in addition to sluice scheduling modes, upstream runoff pollution, pollution sources, and other factors should be considered in the study of pollution loads in rivers. (4) A low level of flow should be maintained at the Huaidian Sluice to encourage self-purification of the water body; jurisdictions in the downstream reach should increase water quality monitoring under high flow rates. (5) Changes in pollutant concentrations at some monitoring points did not conform to expectations; understanding this finding requires further theoretical and numerical simulation research.

Acknowledgments This research was supported by the National Natural Science Foundation of China (nos. 51279183, 51079132, and U1304509) and the Program for Innovative Research Team (in Science and Technology), University of Henan Province (no. 13IRTSTHN030).

\section{References}

Braatne, J. H., Rood, S. B., Goater, L. A., \& Blair, C. L. (2008). Analyzing the impacts of dams on riparian ecosystems: a review of research strategies and their relevance to the Snake River through Hells Canyon. Environmental Management, 41(2), 267-281.

Brandt, S. A. (2000). Classification of geomorphological effects downstream of dams. Catena, 40(4), 375-401.

Campbell, S. G., Hanna, R. B., Flug, M., \& Scott, J. F. (2001). Modeling Klamath River system operations for quantity and quality. Journal of Water Resources Planning and Management, 127(5), 284-294.

Chen, H., Zuo, Q. T., Dou, M., et al. (2014). Comprehensive experimental research on impacts of dam operation on water environment of polluted river. Acta Scientiae Circumstantiae, 34(3), 763-771 (in Chinese).

China State Environmental Protection Administration (2002). Environmental quality standards for surface water-GB 3838-2002. Beijing:China Environmental Science Press (in Chinese).

Chung, S. W., Ko, I. H., \& Kim, Y. K. (2008). Effect of reservoir flushing on downstream river water quality. Environmental Management, 86(1), 139-147.

Di Toro, D. M., Fitzpatrick, J. J., \& Thomann, R. V. (1983). Documentation for water quality analysis simulation program (WASP) and model verification program (MVP). Hydroscience, Westwood, NY.

Gülbahar, N., \& Elhatip, H. (2005). Estimation of environmental impacts on the water quality of the Tahtali dam watershed in Izmir, Turkey. Environmental Geology, 47(5), 725-728.

Hayes, D. F., Labadie, J. W., Sanders, T. G., \& Brown, J. K. (1998). Enhancing water quality in hydropower system operations. Water Resources Research, 34(3), 471-483.

Jae, H. C. (2010). Water quality modeling of a lake considering rainfall runoff pollution loads and water quality improvement by diffuse pollution control. BALWOIS, 25(5), 1-10.

Kurunc, A., Yurekli, K., \& Okman, C. (2006). Effects of Kilickaya Dam on concentration and load values of water quality constituents in KelkitStream in Turkey. Journal of Hydrology, 317(1-2), 17-30.

Lai, Y. C., Tu, Y. T., Yang, C. P., et al. (2013). Development of a water quality modeling system for river pollution index and suspended solid loading evaluation. Journal of Hydrology, 478, 89-101.

Li, D. F., \& Zuo, Q. T. (2012). Study on mechanism of water quality and quantity of heavy pollution river by dam regulating. Water Resources and Power, 30(10), 26-29+213(in Chinese).

Liu, Z. H., Zuo, Q. T., Zhao, G. J., et al. (2011). Experiment of impacts of gate dispatching on water quality of polluted river. Journal of Water Resources and Water Engineering, 22(5), 34-37 (in Chinese).

Mallik, A. U., \& Richardson, J. S. (2009). Riparian vegetation change in upstream and downstream reaches of three temperate rivers dammed for hydroelectric generation in British Columbia, Canada. Ecological Engineering, 35(5), 810-819.

Marcé, R., Moreno-Ostos, E., García-Barcina, J. M., \& Armengol, J. (2010). Tailoring dam structures to water quality predictions in new reservoir projects: assisting decision-making using numerical modeling. Journal of Environmental Management, 91(6), 1255-1267.

Muñoz, J. G., Montalban, F., Gras, J., Rubí, P. G., \& Matador, F. (2005). Environmental integrated rules in dams with water quality problems. The Santomera Dam, an example on how to integrate water quality and water quantity needs. Next 
Generation Geospatial Information: From Digital Image Analysis to Spatiotemporal Databases, pp 237-242.

Newham, L. H., Letcher, R. A., Jakeman, A. J., et al. (2002). Integrated water quality modelling: Ben Chifley Dam catchment, Australia. International Environmental Modelling and Software Society, 1, 275-280.

Petts, G. E., \& Gurnell, A. M. (2005). Dams and geomorphology: research progress and future directions. Geomorphology, $71(1), 27-47$.

State Environmental Protection Administration of China (2002). Monitoring and analysis method of water and waste water. Beijing:China Environmental Science Press (in Chinese).

Stow, C. A., Roessler, C., Borsuk, M. E., Bowen, J. D., \& Reckhow, K. H. (2003). Comparison of estuarine water quality models for total maximum daily load development in Neuse River Estuary. Journal of Water Resources Planning and Management, 129(4), 307-314.

William, L. G. (2006). Downstream hydrologic and geomorphic effects of large dams on American rivers. Geomorphology, 79(3-4), 336-360.

Yangtze Water Environment Monitoring Center (1998). SL 2191998 Regulation for Water Environmental Monitoring. Beijing:China Water Power Press (in Chinese).

Wool, T. A., Ambrose, R. B., Martin, J. L., Comer, E. A., \& Tech, T. (2001). Water quality analysis and simulation program (WASP) version 6.0, Draft User's manual. Atlanta, GA: US Environmental Protection Agency.

Zhang, Y. Y., Xia, J., Wang, G. S., et al. (2007). Research on influence of dams' union dispatch on water quality in Huaihe River Basin. Engineering Journal of Wuhan University, 40(4), 31-35 (in Chinese).

Zhang, Y. Y., Xia, J., Chen, J. F., et al. (2011). Water quantity and quality optimization modeling of dams operation based on SWAT in Wenyu River Catchment, China. Environmental Monitoring and Assessment, 173, 409-430.
Zhang, Y. Y., Xia, J., Liang, T., et al. (2010). Impact of water projects on river flow regimes and water quality in Huai River Basin. Water Resources Management, 24(5), 889908.

Zhang, Y. Y., Xia, J., Shao, Q. X., et al. (2013). Water quantity and quality simulation by improved SWAT in highly regulated Huai River Basin of China. Stochastic Environmental Research and Risk Assessment, 27: 11-27.

Zhang, Y. Y., Xia, J., Shao, Q. X., et al. (2012). Experimental and simulation studies on the impact of sluice regulation on water quantity and quality processes. Journal of Hydrologic Engineering, 17, 467-477.

Zhao, C. S., Sun, C. L., Xia, J., et al. (2010). An impact assessment method of dam/sluice on instream ecosystem and its application to the Bengbu Sluice of China. Water Resources Management, 24, 4551-4565.

Zheng, B. Q., Dou, M., Huang, L. B., et al. (2012). Analysis of sluice operation impact on diversification in water quality. Environmental Science and Technology, 35(2), 14-18+24(in Chinese).

Zheng, C., Yang, W., \& Yang, Z. F. (2010). Environment flows management strategies based on the spatial distribution of water quality, a case study of Baiyangdian Lake, a shallow freshwater lake in China. Procedia Environmental Sciences, 2, 896-905.

Zuo, Q. T., Gao, Y. Y., \& Liu, Z. H. (2010). Analysis and discussion about the mechanisms of the impacts of dams on water quality and quantity of heavily polluted rivers. Resources Science, 32(2), 261-266 (in Chinese).

Zuo, Q. T., Liu, Z. H., Dou, M., et al. (2011). Research framework of assessment of dams' impact on water quality and quantity and identification of regulation ability. South-to-North Water Diversion and Water Science and Technology, 9(2), 18-21+ 40(in Chinese). 